\title{
RISK MITIGATION AND OPTIMIZATION USE OF RUNOFF WATER IN WADI AI- ASSUITY, EASTERN DESERT OF EGYPT
}

\author{
Abo El-Nasr, M. M. ${ }^{(1)}$; Saqr, S. A. ${ }^{(2)}$; Ismail, Y. L. ${ }^{(3)}$; Abotaleb, H. A. ${ }^{(1)}$ \\ and Hamdy, M. M. \\ 1) Mechanical Power Engineering Dep., Faculty of Engineering, Ain Shams \\ University. 2) Groundwater Sector, Ministry of Water Resource and \\ Irrigation. 3) Hydrology Department, Desert Research Center.
}

\begin{abstract}
Egypt is currently suffering from water shortages. This shortage is expected to increase significantly, as a result of increased population growth, agricultural and industrial activities, and development demands. So it was important to research the storage and the optimal use of any possible water resources that could contribute to the provision of any amount of water no matter how small or large the quantity. As the Eastern Desert of Egypt is full of wadis, which are subject to sudden rainfall, huge amount of runoff water is wasted. Water flows over the ground to dry either by evaporation or by the amount of water that leaks through the soil. Moreover, over the years, these floods have caused disasters, threats and destruction to villages and towns.

Since Egypt needs every drop of water, floodwaters may cover part of these needs. This paper contributes to the mitigation of the dangers of flood waters in Wadi Al- Assuity in the Eastern Desert of Egypt, finding practical solutions for storing them, protecting villages from their disasters and using their water to achieve sustainable development in the surrounding environment.

The results of this research are summarized in the assessment of the Wadi Al- Assuity in terms of: determination of geomorphological characteristics, estimation and evaluation of the size of the annual precipitation and the size of the floods that threaten the urban communities located on the basin's ports, mitigate the risks and threats of this basin by taking advantage of the flood waters and taking them as a source of water.
\end{abstract}


Methods of storage and use of flood water through the construction of check dams and protection dams, cisterns (reservoirs), collection ponds, or others.

Keywords: Runoff, Water Harvesting, Geomorphology.

\section{Location and Climate}

adi Al- Assiuty is located at the western side of the Eastern Desert and drains its surface runoff toward the Nile River. It covers a catchment area around $6049.35 \mathrm{~km}^{2}$; the area is enclosed by latitudes $25^{\circ} 50^{\prime} 00^{\prime \prime}$ and $26^{\circ} 15^{\prime}$ $00^{\prime \prime}$ North and longitudes $33^{\circ} 45^{\prime} 00^{\prime \prime}$ and $34^{\circ} 11^{\prime} 00^{\prime \prime}$ East. Figure 1 shows the location of Wadi Al- Assuity Basin. The maximum temperature during the year reaches $38^{\circ} \mathrm{C}$ in January, while the minimum temperature recorded is $7.0^{\circ} \mathrm{C}$ in June; the average daily relative humidity ranges from $28 \%$ in spring and summer, and increases to around $52 \%$ in winter and fall (Sulaiman; Abdel Aziz, 2001). According to EMA, the evaporation rate increases southward; the maximum mean of evaporation varies from 3.2 $\mathrm{mm} / \mathrm{month}$ in January and up to $12.1 \mathrm{~mm} / \mathrm{month}$ in June, the annual rainfall is about $0.2 \mathrm{~mm} /$ month during the period from 1981 to 2010 , and the total Radiation varies from $13.88 \mathrm{MJ} / \mathrm{m}^{2}$ in January to $28.84 \mathrm{MJ} / \mathrm{m}^{2}$ in June. Rainfall varies from season to another. Even though, rainfall events are rare, many flash floods are reported in the Eastern Desert. Table 1 shows the monthly averages of the meteorological data of Wadi Al-Assuity according to Assuit Station in the period from 1981 to 2010. Figure 2 shows the relation of total rainfall vs. months, figure 3 shows the relation of evaporation quantity vs. months, and figure 4 shows the relation of total Emission vs. Months of Wadi Al- Assuity.

\section{General Geology \& Geomorphology of Wadi Al-Assuity:}


Wadi Al- Assuity sedimentary basin rocks are characterized by homogeneous geological deposits. The rock formations in Wadi Al- Assuity basin belong to Tertiary and Quaternary deposits. The Eocene rocks are considered the oldest most prevalent surface rocks in the basin, covering more than $91 \%$ of its total area of the Wadi, while, less than $1 \%$ of the area is formed during the Era of Pliocene Rocks, and $8 \%$ of the total area of the basin is formed of the deposits which represent the Quaternary age. The Eocene Formations are represented in both formations: Drunka and Serri (Early Eocene: Menia Formation, and Middle Eocene), while Pliocene Formations is represented in Qena and Armant Formation. Figure 5 shows geological map of Wadi Al- Assuity.

The Quaternary deposits are represented in floodplains' terraces, alluvial fans, wadi padding deposits, and sand formations, scattered on the slopes of the wadis. Main and secondary cracks effect the directions of waterways, and the distribution of the major landforms in the basin. 
J. Environ. Sci.

Institute of Environmental Studies and Research - Ain Shams University

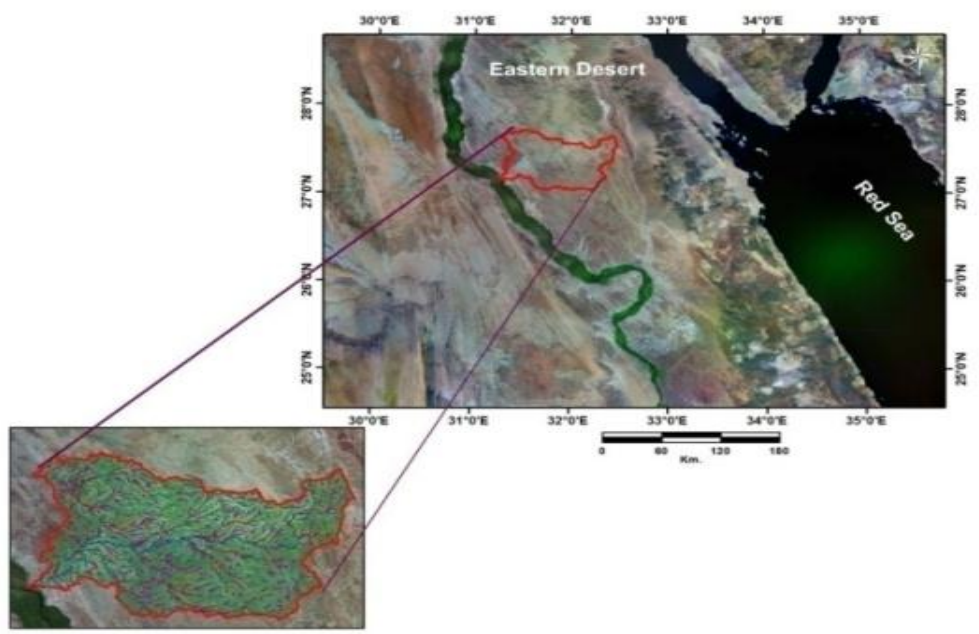

Figure 1 Location of Wadi Al- Assuity.

Source: Egyptian Geological Survey (EGS) - The Egyptian Mineral Resources Authority (EMRA). 
Table 1: Monthly Averages of the Meteorological Data of Wadi Al- Assuity According to Assuit Station in the Period from 1981 to 2010.

\begin{tabular}{||c|c|c|c|c|c|c||}
\hline \hline Month & $\begin{array}{c}\text { Total } \\
\text { Rainfall } \\
\text { (mm/month) }\end{array}$ & $\begin{array}{c}\text { Largest } \\
\text { Quantity } \\
\text { (mm/Month) }\end{array}$ & $\begin{array}{c}\text { Date of } \\
\text { Occurrence } \\
\text { (D/M/Year) }\end{array}$ & $\begin{array}{c}\text { Period of } \\
\text { Rainfall } \\
\text { (Min.) }\end{array}$ & $\begin{array}{c}\text { Evaporation } \\
\text { Quantity } \\
\text { (mm/Month) }\end{array}$ & $\begin{array}{c}\text { Total } \\
\text { Emission } \\
\left(\mathbf{M J} / \mathbf{m}^{\mathbf{2}}\right)\end{array}$ \\
\hline \hline January & 0.170 & 04.00 & $01 / 01 / 1994$ & 52 & 3.20 & 13.88 \\
\hline February & 0.090 & 00.09 & $07 / 02 / 2000$ & 25 & 4.30 & 17.41 \\
\hline March & 0.450 & 10.70 & $19 / 03 / 1995$ & 120 & 5.90 & 21.63 \\
\hline April & 0.050 & 01.10 & $03 / 04 / 2001$ & 40 & 8.5 & 24.86 \\
\hline May & 0.060 & 01.80 & $08 / 05 / 1990$ & 45 & 10.60 & 26.61 \\
\hline June & 0.000 & 00.00 & - & - & 12.10 & 28.84 \\
\hline July & 0.000 & 00.00 & - & - & 11.30 & 28.01 \\
\hline August & 0.000 & 00.00 & - & - & 12.10 & 26.17 \\
\hline September & 0.000 & 00.00 & - & - & 08.50 & 23.16 \\
\hline October & 0.002 & 00.10 & $10 / 10 / 1994$ & 18 & 6.90 & 18.94 \\
\hline November & 1.250 & 24.00 & $01 / 11 / 1994$ & 60 & 4.60 & 14.98 \\
\hline December & 0.110 & 02.00 & $29 / 12 / 2010$ & 30 & 3.20 & 12.84 \\
\hline
\end{tabular}

Source: Egyptian Meteorological Authority (EMA).

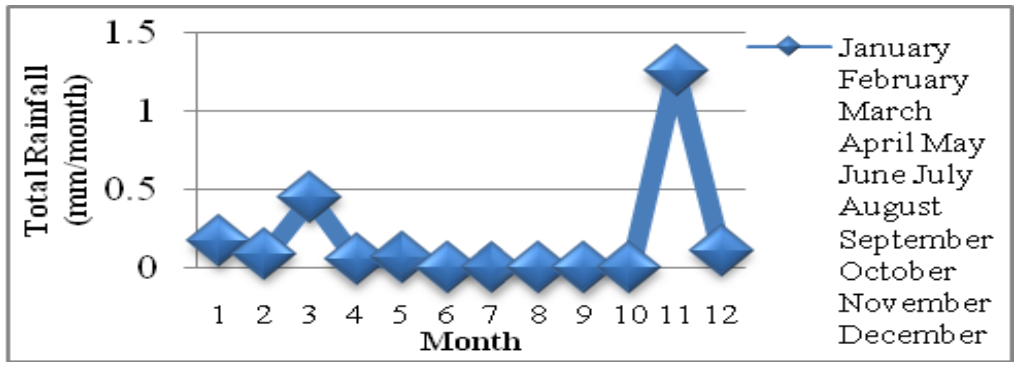

Figure 2 Wadi Al- Assuity, Total Volume Rainfall vs. Months.

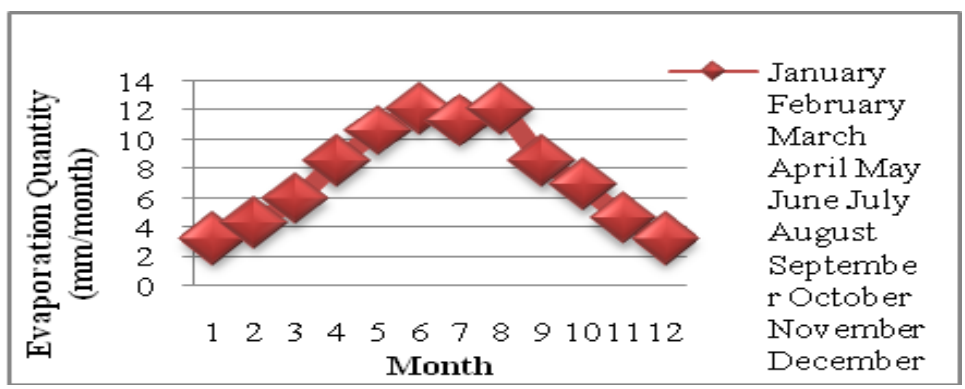

Figure 3 Wadi Al- Assuity, Evaporation vs. Months

Vol. 40, No.3, Dec. 2017 
J. Environ. Sci.

Institute of Environmental Studies and Research - Ain Shams University

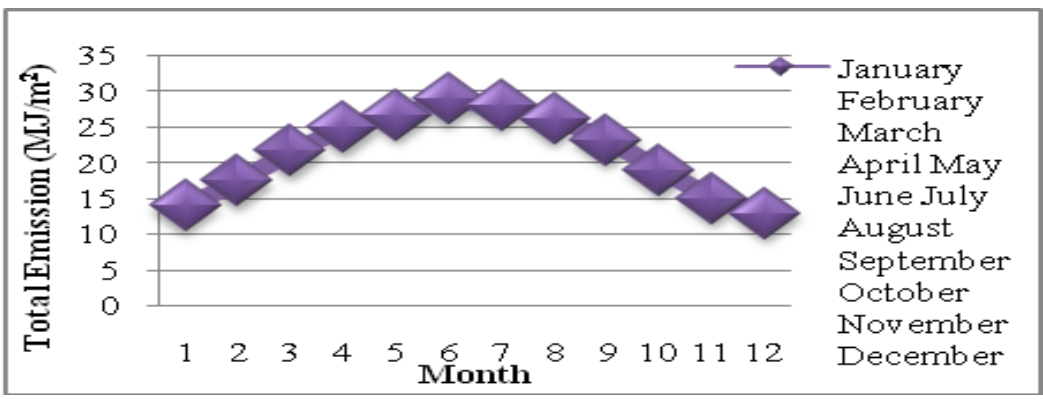

Figure 4 Wadi Al- Assuity, Total Emission vs. Months

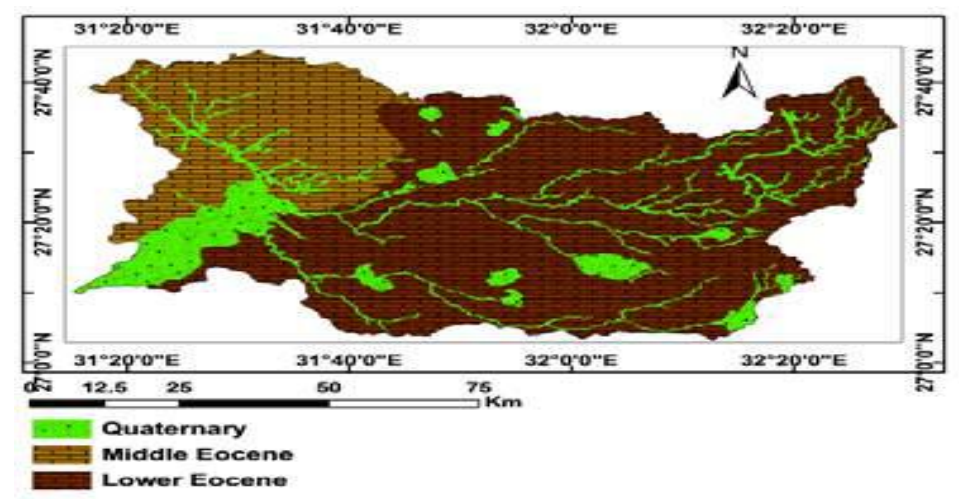

Figure 5 Geological Map of Wadi Al- Assuity (Milad, 2013).

\section{Morphometric Analysis of Wadi Al-Assuity:}

\section{A. Linear Aspects:}

A-1 Stream Order $\left(\mathbf{N}_{\underline{u}}\right)$ : Stream order represents the hierarchical ranking of the streams (Strahler, 1964). Horton's law shows that there is an inverse relation between the order of the streams and their numbers; the less the number of streams, the greater the order of the stream, forming reverse geometric sequence (Horton, 1945). Stream orders of Wadi Al- Assuity are as follows: $\mathrm{N}_{1}=2804, \mathrm{~N}_{2}=611, \mathrm{~N}_{3}=136, \mathrm{~N}_{4}=30, \mathrm{~N}_{5}=6, \mathrm{~N}_{6}=1$; figure 6 shows basin stream orders of Wadi Al- Assuity. The total number of 
streams is 3588 . The $1^{\text {st }}$ order occupies $78.15 \%, 2^{\text {nd }}$ order occupies $17.03 \%, 3^{\text {rd }}$ order occupies $3.79 \%, 4^{\text {th }}$ order occupies $0.84 \%, 5^{\text {th }}$ order occupies $0.17 \%, 6^{\text {th }}$ order occupies $0.02 \%$ from the total stream orders.

A-2 Stream Length $\left(\mathbf{L}_{\mathbf{u}}\right)$ : Stream length represents the length of the total lengths of all stream lengths in the basin (Horton, 1945). The Stream lengths are as follows: $\mathrm{L}_{1}=3090656 \mathrm{~m}=3090.656 \mathrm{~km}, \mathrm{~L}_{2}=1497159$ $\mathrm{m}=1497.159 \mathrm{~km}, \mathrm{~L}_{3}=764337 \mathrm{~m}=764.337 \mathrm{~km}, \mathrm{~L}_{4}=499625 \mathrm{~m}=499.625 \mathrm{~km}$, $\mathrm{L}_{5}=235239 \mathrm{~m}=235.239 \mathrm{~km}, \mathrm{~L}_{6}=143314 \mathrm{~m}=143.314 \mathrm{~km}$. The total stream lengths' is $6230.330 \mathrm{~km}$. The $1^{\text {st }}$ order lengths occupy $49.61 \%, 2^{\text {nd }}$ order lengths occupy $24.03 \%, 3^{\text {rd }}$ order lengths occupy $12.27 \%, 4^{\text {th }}$ order lengths occupy $8.02 \%, 5^{\text {th }}$ order lengths occupy $3.78 \%, 6^{\text {th }}$ order lengths occupy $2.30 \%$ from the total stream lengths.

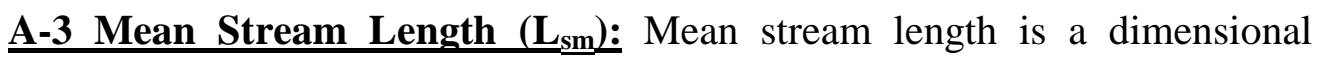
property which reveals the characteristic size of the drainage network components and its contribution to watershed surfaces. Mostly, it is observed that the mean stream length of any given order is greater than that of the lower order but less than that of the next higher order. In Wadi Al- Assuity mean stream lengths: $\mathrm{L}_{\mathrm{sm}}=\mathrm{L}_{\mathrm{u}} / \mathrm{N}_{\mathrm{u}}$ (Strahler, 1964), $\mathrm{L}_{\mathrm{sm} 1}=$ $3090.656 / 2804=1.102 \mathrm{~km}, \quad \mathrm{~L}_{\mathrm{sm} 2}=1497.159 / 611=2.450 \quad \mathrm{~km}, \quad \mathrm{~L}_{\mathrm{sm} 3}=$ $764.337 / 136=5.620 \mathrm{~km}, \mathrm{~L}_{\mathrm{sm} 4}=499.625 / 30=16.654 \mathrm{~km}, \mathrm{~L}_{\mathrm{sm} 5}=$ $235.239 / 6=39.207 \mathrm{~km}, \mathrm{~L}_{\mathrm{sm} 6}=143.314 / 1=143.314 \mathrm{~km}$. Mean stream length varies between $1.102 \mathrm{~km}$ (lowest value, $1^{\text {st }}$ order), and $143.314 \mathrm{~km}$ (highest value, $6^{\text {th }}$ order). 


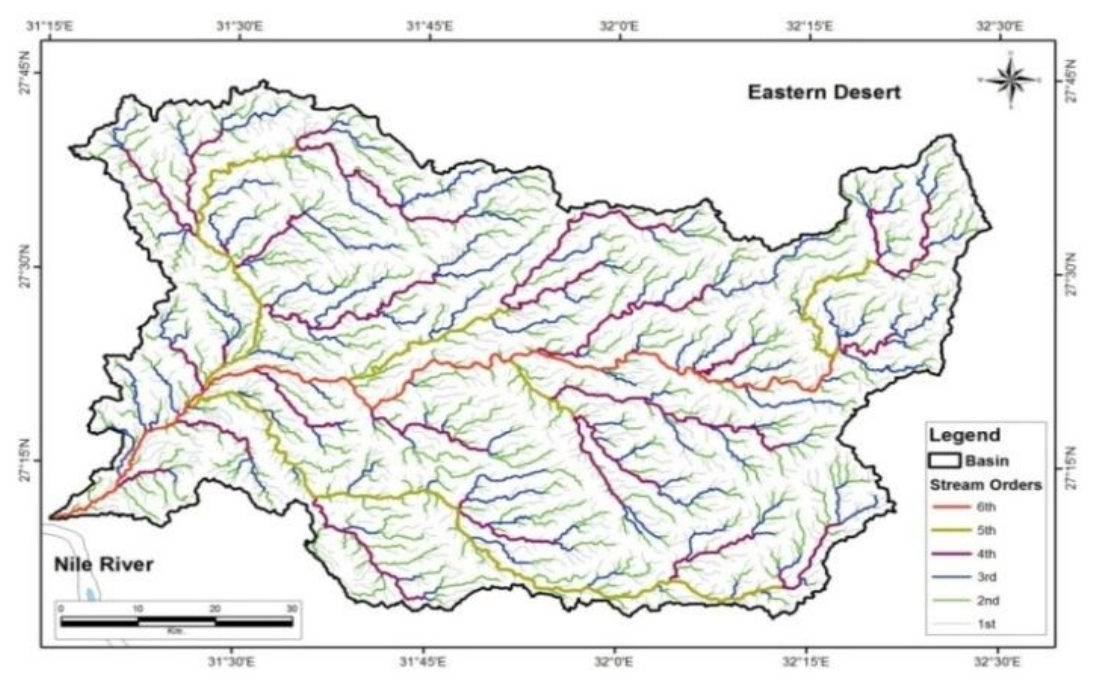

Figure 6 Basin Stream Orders of Wadi Al- Assuity.

Source: Egyptian Geological Survey (EGS) - The Egyptian Mineral Resources Authority (EMRA).

A-4 Stream Length Ratio $\left(\mathbf{R}_{\mathrm{L}}\right): \mathrm{R}_{\mathrm{L}}$ between successive stream orders of the sub-watershed vary according to differences in slope and topographic conditions. In Wadi Al- Assuity: $\mathrm{R}_{\mathrm{L}}=\mathrm{L}_{\mathrm{sm}} / \mathrm{L}_{\mathrm{sm}-1}$ (Horton, 1945), $\mathrm{R}_{\mathrm{L} 1}=2.223$, $\mathrm{R}_{\mathrm{L} 2}=2.294, \mathrm{R}_{\mathrm{L} 3}=2.963, \mathrm{R}_{\mathrm{L} 4}=2.354, \mathrm{R}_{\mathrm{L} 5}=3.655$. The values of the mean $\mathrm{R}_{\mathrm{L}}$ varies from 2.223 to 3.655 ; this variation between orders is due to the difference in slope and topographic conditions.

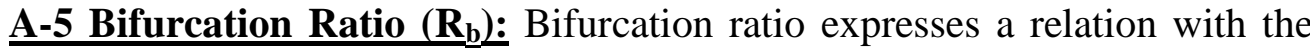
geometric shape of the basin which affects the rate of discharge and time of concentration. In Wadi Al- Assuity: $\mathbf{R}_{\mathbf{b}}=\mathbf{N}_{\mathbf{u}} / \mathbf{N}_{\mathbf{u}+\mathbf{1}}$ (Schumm, 1956), $\mathrm{R}_{\mathrm{b} 1}=4.589, \mathrm{R}_{\mathrm{b} 2}=4.493, \mathrm{R}_{\mathrm{b} 3}=4.533, \mathrm{R}_{\mathrm{b} 4}=5, \mathrm{R}_{\mathrm{b} 5}=6$. 


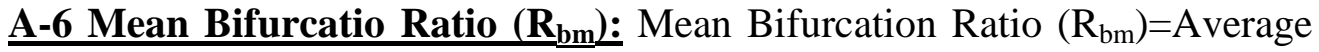
of bifurcation ratio of all orders (Strahler, 1964). $R_{b}=R_{b m}=4.923 \rightarrow R_{b}$ for the whole basin $=4.923$. The lower the proportion of bifurcation ratio, the faster surface water is produced giving the opportunity to increase the probability of flooding in the area, and vice versa. In Wadi Al- Assuity, bifurcation ratio reached 4.923 .

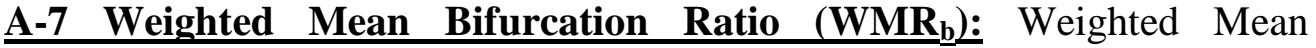

Bifurcation Ratio is the product of multiplying the bifurcation ratio for each successive pair of order by the total number of stream involved in the ratio and taken the mean of the sum of these values.

$\left.\mathrm{WMR}_{\mathrm{b}}=\sum\left\{\left[\mathrm{R}_{\mathrm{b}(\mathrm{u})} / \mathrm{R}_{\mathrm{b}(\mathrm{u}+1)}\right] \times\left(\mathrm{N}_{\mathrm{u}}+\mathrm{N}_{\mathrm{u}+1}\right)\right]\right\} / \sum \mathrm{N}$ (Strahler, 1953) $=1.229$

A-8 RHO Coefficient (RHO): According to Horton, RHO is considered as an important parameter as it determines the relationship between the drainage density and the physiographic development of the basin and allows the evaluation of the storage capacity of the drainage network. In Wadi Al- Assuity: $\mathrm{RHO}=\mathrm{R}_{\mathrm{l}} / \mathrm{R}_{\mathrm{b}}$ (Horton, 1945), $\mathrm{RHO}_{1}=0.495$, $\mathrm{RHO}_{2}=0.506, \mathrm{RHO}_{3}=0.593, \mathrm{RHO}_{4}=0.392$.

\section{B. Areal Aspects}

The definition of areal aspects of a watershed of given order is the total area projected upon a horizontal plane, contributing overland flow to the channel segment of the given order including all tributaries of lower order.

B-1 Basin Area $\left(\mathbf{A}_{\mathbf{b}}\right)$ : Basin area of Wadi Al- Assuity drainage basin is measured by using the program ArcGIS version 10.5. The basin area of Wadi Al- Assuity is: $A_{b}=6049350000 \mathrm{~m}^{2}=6049.350000 \mathrm{~km}^{2}$. 
B-2 Perimeter $\left(\mathbf{P}_{\mathbf{b}}\right)$ : The basin perimeter $(\mathrm{P})$ describes the circularity of the basin. Basin perimeter is defined as the length of the curve that defines the surface divide of the drainage basin (Horton, 1945). Basin perimeter of Wadi Al- Assuity drainage basin is measured by using the program ArcGIS version 10.5. The perimeter of Wadi Al- Assuity is: $\mathrm{P}_{\mathrm{b}}=524758$ $\mathrm{m}=524.758 \mathrm{~km}$.

B-3 Basin Length $\left(\mathbf{L}_{\mathbf{b}}\right)$ : The basin length $\left(\mathrm{L}_{\mathrm{b}}\right)$ is the shortest line dividing the basin into two halves running from the mouth to the source. Wadi AlAssuity basin length is: $\mathrm{L}_{\mathrm{b}}=127250 \mathrm{~m}=127.250 \mathrm{~km}$.

B-4 Drainage Density $\left(\mathbf{D}_{\mathbf{d}}\right)$ : Drainage density is the total length of streams of different orders $\sum \mathrm{L}_{\mathrm{u}}$ per unit of area $\mathrm{A}$. The drainage density of Wadi AlAssuity is: $D_{d}=\sum L_{u} / A_{b}=1.030$ (Horton, 1932). The low value of $D_{d}$ shows that the region is very rough.

B-5 Stream Frequency: Stream Frequency is the ratio of the total number of stream segments of all orders within a given basin to the total area of the basin. According to Zakrzenska (Zakrzenska, 1967), the results of this equation are:

- If $\mathrm{F}_{\mathrm{s}}$ less than 4, then the topographic texture is rough.

- If $F_{\mathrm{s}}$ ranged (4 - 10), then the topographic texture is medium roughness.

- If $\mathrm{F}_{\mathrm{s}}$ more than 10, then the topographic texture is fine.

$$
\mathrm{F}_{\mathrm{s}}=\sum \mathrm{N}_{\mathrm{u}} / \mathrm{A}_{\mathrm{b}} \mathrm{km}^{-2}=0.593 \mathrm{~km}^{-2} \quad \text { (Horton, 1932) }
$$

The stream frequency value of Wadi Al- Assuity is $0.5931 \mathrm{~km}^{-2}$ which is less than 4; this reflects the rough coarse texture topography of the area. 
B-6 Length of Overland Flow $\left(\mathbf{L}_{0}\right)$ : Horton defined the length of overland flow as the length of flow path which is projected to a horizontal plane of the rain flow from a point on the drainage divide to a point on the adjacent stream channel. The shorter the length of overland flow, the quicker the surface runoff from the streams (Kumar; Jayappab; Deepika, 2011). In Wadi Al-Assuity $\mathrm{L}_{\mathrm{o}}$ is: $\mathrm{L}_{\mathrm{o}}=1 / 2 \mathrm{D}_{\mathrm{d}}=0.515$ (Horton, 1945).

B-7 Drainage Texture Ratio $\left(\mathbf{D}_{t}\right)$ : Drainage texture is the ratio of the total number of basin segments to its perimeter. $\mathrm{D}_{\mathrm{t}}=\sum \mathrm{N}_{\mathrm{u}} / \mathrm{P}_{\mathrm{b}} \mathrm{Km}^{-1}$ (Horton, 1945). Smith categorized the texture ratio of basins into three categories: (Fine $>16 \mathrm{~km}^{-1}$, Moderate 6.4 to $16 \mathrm{~km}^{-1}$, Coarse $<6.4 \mathrm{~km}^{-1}$ ) (Smith, K.G. 1950)

While Morisawa (Morisawa, 1985) divided the relation between texture ratio and drainage density into four categories as follows; Table 2:

Table 2 Morisawa's Categorization.

\begin{tabular}{|c|c|c|}
\hline $\begin{array}{l}\text { Texture } \\
\text { Ratio }\end{array}$ & $\begin{array}{c}\text { Drainage } \\
\text { Density }\end{array}$ & Conditions \\
\hline Rough & $<8$ & $\begin{array}{c}\text { Resistant or permeable rocks + good natural } \\
\text { plant }\end{array}$ \\
\hline Medium & $8-20$ & $\begin{array}{c}\text { Resistant or permeable rocks + considerable } \\
\text { precipitation + good natural plant }\end{array}$ \\
\hline Fine & $20-200$ & $\begin{array}{c}\text { Non-permeable surface }+ \text { severe precipitation }+ \\
\text { lack of plant natural }\end{array}$ \\
\hline Very Fine & $>200$ & $\begin{array}{c}\text { Non-permeable surface }+ \text { heavy precipitation }+ \\
\text { weak rocks }+ \text { natural plant scarcity }\end{array}$ \\
\hline
\end{tabular}

$$
D_{\mathbf{t}}=\sum \mathbf{N}_{\mathbf{u}} / \mathbf{P}_{\mathrm{b}} \mathbf{k m}^{-1}=6.837 \mathrm{~km}^{-1}
$$

According to Smith categorized the texture ratio of basins, Wadi AlAssuity is located in the moderate range (between 6.4 to $16 \mathrm{~km}^{-1}$ ). According to Morisawa, this value of drainage texture ratio which is 6.837 , this indicates 
that the basin consists of permeable rocks, heavy rain, and good natural plants.

B-8 Basin Shape: Basin shape is determined through four equations:

- Circularity Ratio $\left(\boldsymbol{R}_{c}\right)$ : The value of circulation ratio ranges between zero and one. The greater the value of circulation ratio is the more circular the shape of the basin. While the less the value of circularity ratio, means the irregularity of the water distribution lines surrounding the basin. The circularity ratio $\left(\mathrm{R}_{\mathrm{c}}\right)$ of Wadi Al- Assuity is: $\mathrm{R}_{\mathrm{c}}=4 \pi \mathrm{A}_{\mathrm{b}} / \mathrm{P}_{\mathrm{b}}{ }^{2}=0.276$ (Miller, 1953). Circularity ratio value in Wadi Al- Assuity is 0.275918, which is considered as a low value; i.e. less circular. This indicates that the water distribution lines of the basin of the study area are skewed.

- Elongation Ratio $\left(\boldsymbol{R}_{e}\right)$ : Elongation ratio value ranges between zero and one. If the elongation ratio approaches zero that means that the basin shape is similar to the shape of the rectangle. If the elongation ratio approaches one, then the basin shape is circular. The elongation ratio of Wadi AlAssuity is: $R_{e}=2\left(A_{b} / \pi\right)^{0.5} / L_{b}=0.690$ (Schumm, 1956). The value of elongation ratio is 0.690 which is considered as a medium value. That means that stones contain many rifts and cracks as a result of the impact of the cracking processes that accompanied the formation of the Red Sea groove, which helped to develop the drainage network and the extension of the streams, which in turn, is reflected on the shape of the basin. Therefore, the basin is characterized by a regular slope along the sector of its main streams. 
- Shape Index $\left(\boldsymbol{I}_{s h}\right)$ : Whenever the value of shape index get closer to value one, then the shape of the basin is more regular and homogeneous, while the lower values of shape index means that the shape of the basin is irregular, then the basin shape form looks like a triangle where its head is heading towards downstream. The value of $\mathrm{I}_{\text {sh }}$ in Wadi Al- Assuity is: $\mathrm{I}_{\mathrm{sh}}=\mathrm{A}_{\mathrm{b}} / \mathrm{L}_{\mathrm{b}}{ }^{2}=0.374$ (Hagget, 1956) which is considered a medium value. This indicates a medium consistency and harmony. The shape of the basin is less triangular shape that heads towards downstream.

- Infiltration Number (If): Infiltration number of a drainage basin is the product of drainage density and stream frequency. The higher the infiltration number, the lower will be the infiltration and higher will be the run-off (K. Rao; Rehman; and Yusuf 2011). I of Wadi Al- Assuity is: $\mathrm{I}_{\mathrm{f}}=\mathrm{D}_{\mathrm{d}} \mathrm{xF} \mathrm{F}_{\mathrm{s}}=0.611$ (Zavoiance, 1985).

C. Relief Aspects: Relief characteristics are determined through four equations:

C-1 Basin Relief (R): Basin relief is the difference in elevation between the remotest point in the water divide line and the discharge point is obtained from the available DEM. Basin relief of Wadi Al- Assuity is: $\mathrm{R}=\mathrm{H}$ $\mathrm{h}=0.820$ (Hadley; Schumm, 1961). Figure 7 shows digital elevation model DEM of Wadi Al- Assuity.

C-2 Relief Ratio $\left(\mathbf{R}_{\mathrm{f}}\right)$ : According to Schumn, $\mathbf{R}_{\mathrm{f}}$ is the ratio of maximum watershed relief to the horizontal distance along the longest dimension of the watershed parallel to the principal drainage line. The value of relief ration ranges from zero to one. The relief ratio of Wadi Al- Assuity is: $R_{h}$ $=\mathrm{R} / \mathrm{L}_{\mathrm{b}}=0.006($ Schumm, 1956). 
J. Environ. Sci.

Institute of Environmental Studies and Research - Ain Shams University

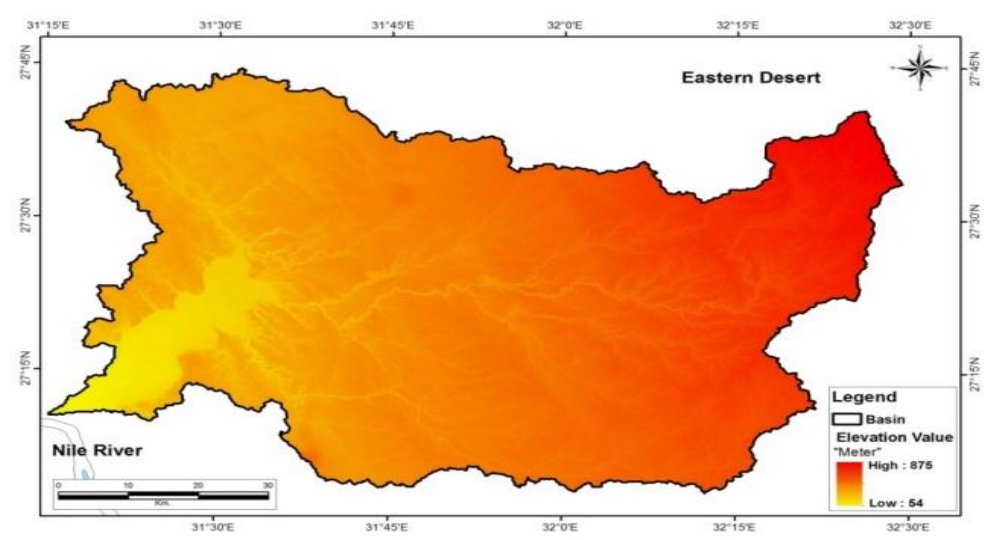

Figure 7 Digital Elevation Model DEM of Wadi Al- Assuity.

Source: Egyptian Geological Survey (EGS) -The Egyptian Mineral Resources Authority (EMRA).

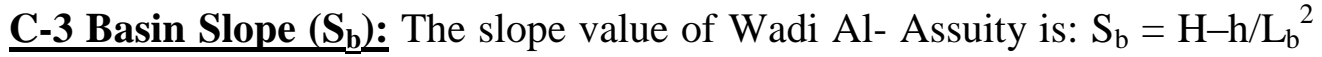
$=0.00005$ (Mesa, 2006).

C-4 Ruggedness Number $\left(\mathbf{R}_{\mathbf{n}}\right)$ : The degree of ruggedness indicates how much the surface of the pelvis is cut by wadis. High values of the $R_{n}$ in the watershed are because both the variables like relief and drainage density are enlarged. High value of ruggedness number occurs for a high relief region with high stream density. The ruggedness number of Wadi AlAssuity is: $R_{n}=D_{d} \times R=0.845$ (Melton, 1958). 
Table 4 shows the main morphometric parameters of Wadi Al- Assuity.

Table 5 shows the summary of geomorphologic parameters.

\begin{tabular}{|c|c|c|}
\hline & Item & Value \\
\hline & Basin Area $\left(\mathrm{A}_{\mathrm{b}}\right)\left(\mathrm{m}^{2}\right)$ & 6049350000 \\
\hline & Basin Area $\left(\mathrm{A}_{\mathrm{b}}\right)\left(\mathrm{km}^{2}\right)$ & 6049.350 \\
\hline & Basin Perimeter $\left(\mathrm{P}_{\mathrm{b}}\right)(\mathrm{m})$ & 524758 \\
\hline & Basin Perimeter $\left(\mathrm{P}_{\mathrm{b}}\right)(\mathrm{km})$ & 524.758 \\
\hline & Basin Length $\left(\mathrm{L}_{\mathrm{b}}\right)(\mathrm{m})$ & 127250 \\
\hline & Basin Length $\left(\mathrm{L}_{\mathrm{b}}\right)(\mathrm{km})$ & 127.250 \\
\hline Areal & Basin Width $(\mathrm{m})$ & 82144 \\
\hline & Basin Width $(\mathrm{km})$ & 82.144 \\
\hline Aspects & Drainage Density $\left(\mathrm{D}_{\mathrm{d}}\right)$ & 1.030 \\
\hline & Stream Frequency $\left(\mathrm{F}_{\mathrm{s}}\right)\left(\mathrm{km}^{-2}\right)$ & 0.593 \\
\hline & Length of Over Land Flow $\left(\mathrm{L}_{\mathrm{o}}\right)$ & 0.515 \\
\hline & Drainage Texture Ratio $\left(\mathrm{D}_{\mathrm{f}}\right)\left(\mathrm{km}^{-1}\right)$ & 6.837 \\
\hline & Circularity Ratio $\left(\mathrm{R}_{\mathrm{c}}\right)$ & 0.276 \\
\hline & Elongation Ratio $\left(\mathrm{R}_{\mathrm{e}}\right)$ & 0.690 \\
\hline & Shape Index $\left(\mathrm{I}_{\mathrm{sh}}\right)$ & 0.374 \\
\hline & Infiltration Number $\left(\mathrm{I}_{\mathrm{f}}\right)$ & 0.611 \\
\hline & Basin Relief $(\mathrm{R})(\mathrm{km})$ & 0.820 \\
\hline Relief & Relief Ratio $\left(\mathrm{R}_{\mathrm{f}}\right)$ & 0.006 \\
\hline & Basin Slope $\left(\mathrm{S}_{\mathrm{b}}\right)$ & 0.00005 \\
\hline & Ruggedness Number $\left(\mathrm{R}_{\mathrm{n}}\right)$ & 0.845 \\
\hline
\end{tabular}


J. Environ. Sci.

Institute of Environmental Studies and Research - Ain Shams University

Table 5 Summary of Geomorphologic Parameters of Wadi Al- Assuity.

\begin{tabular}{|c|c|c|c|c|c|c|c|}
\hline Order & 1 & 2 & 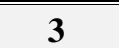 & 4 & 5 & 6 & Total \\
\hline $\begin{array}{ll}\text { Number } & \text { of } \\
\text { Streams } & \end{array}$ & 2804 & 611 & 136 & 30 & 6 & 1 & 3588 \\
\hline $\begin{array}{l}\text { Percentage of } \\
\text { Stream Order }(\%)\end{array}$ & 78.15 & 17.03 & 3.79 & 0.84 & 0.17 & 0.02 & 100 \\
\hline Length (m) & 3090656 & 1497159 & 764337 & 499625 & 235239 & 143314 & 62303300 \\
\hline Length (km) & 3090.656 & 1497.159 & 764.337 & 499.625 & 235.239 & 143.314 & 6230.330 \\
\hline $\begin{array}{l}\text { Percentage } \\
\text { Length }(\%)\end{array}$ & 49.61 & 24.03 & 12.27 & 8.02 & 3.78 & 2.30 & 100 \\
\hline $\begin{array}{l}\text { Mean Stream } \\
\text { Length } \\
(\mathrm{Lsm})(\mathrm{m})\end{array}$ & 1102.23 & 2450.34 & 5620.13 & 16654.17 & 39206.5 & 143314 & \\
\hline $\begin{array}{l}\text { Mean Stream } \\
\text { Length } \\
(\mathrm{Lsm})(\mathrm{km})\end{array}$ & 1.1023 & 2.45034 & 5.62013 & 16.6541 & 39.207 & 143.314 & \\
\hline $\begin{array}{l}\text { Stream Length } \\
\text { Ratio (RL) }\end{array}$ & & 2.223 & 2.294 & 2.963 & 2.354 & 3.655 & \\
\hline $\begin{array}{l}\text { Bifurcation Ratio } \\
(\mathrm{Rb})\end{array}$ & 4.589 & 4.493 & 4.533 & 5 & 6 & & \\
\hline $\begin{array}{l}\text { Mean Bifurcation } \\
\text { Ratio }(\mathrm{Rbm})\end{array}$ & & & & & & & 4.923 \\
\hline $\begin{array}{l}\text { Weighted Mean } \\
\text { Bifurcation Ratio } \\
(\text { WMRb) }\end{array}$ & & & & & & & 1.229 \\
\hline $\begin{array}{l}\text { RHO Coefficient } \\
\text { (RHO) }\end{array}$ & & 0.495 & 0.506 & 0.593 & 0.392 & & \\
\hline
\end{tabular}

\section{RESULTS AND CALCULATIONS}

In order to analyze the data of the study Wadi, three computer software packages were used: SMADA version 6, AQTESOLV version 4, and GWW version 3 .

1. Use SMADA Program and input data of Wadi Al- Assuity shown in

Table 6 to get watershed hydrograph, and rainfall hydrograph of Wadi Al-

Assuity shown in Figures 8, and 9. 
Table 6 Input Data of Wadi Al- Assuity.

\begin{tabular}{|l|c|}
\hline \multicolumn{1}{|c|}{ Catchment Area $\left(\mathbf{k m}^{2}\right)$} & $\mathbf{6 0 4 9 . 3 5 0}$ \\
\hline Duration of Peak Storm & 60 \\
\hline Time Interval (minutes) & 5 \\
\hline Infiltration Rate & 0.5 \\
\hline Low Infiltration Rate (m/day) & 1.7 \\
\hline High Infiltration Rate (m/day) & 0.006 \\
\hline Slope of Mini Channel (Dimensionless) & \\
\hline
\end{tabular}

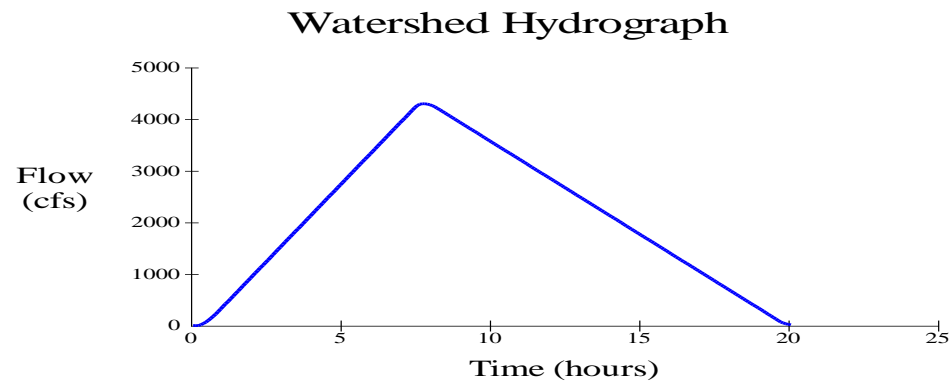

Figure 8 Hydrograph of Wadi Al- Assiuty.

\section{Output Data:}

Total Volume Runoff $=4,354,242.664 \mathrm{~m}^{3}$

Time to Peak $=8 \mathrm{hrs}=480 \mathrm{~min}$

Base Time $=20 \mathrm{hrs}=1200 \mathrm{~min}$

Peak of Discharge $=4300 \mathrm{ft}^{3} / \mathrm{sec}=121.69 \mathrm{~m}^{3} / \mathrm{sec}$

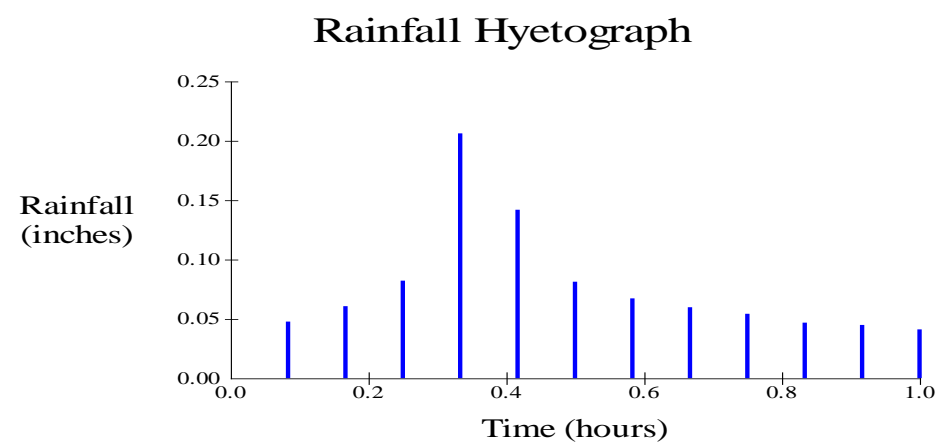

Figure 9 Rainfall Hyetograph of Wadi Al- Assiuty. 
J. Environ. Sci.

Institute of Environmental Studies and Research - Ain Shams University

\section{Well Efficiency and Productivity of the Productive Wells}

By using GWW Program, and input data of Wadi Al- Assuity shown in

Table 7 to get the analysis of step-drawdown test data of the Well: AlAssuity; Figure 10. The output data is shown in Table 8.

Table 7 Results of Step - Drawdown Tests.

\begin{tabular}{|c|c|c|c|}
\hline Steps & First & Second & Third \\
\hline \hline Drawdown $(\mathrm{m})$ & 28.7 & 35 & 47 \\
\hline Discharge $\left(\mathrm{m}^{3} / \mathrm{hr}\right)$ & 40 & 45 & 58 \\
\hline
\end{tabular}

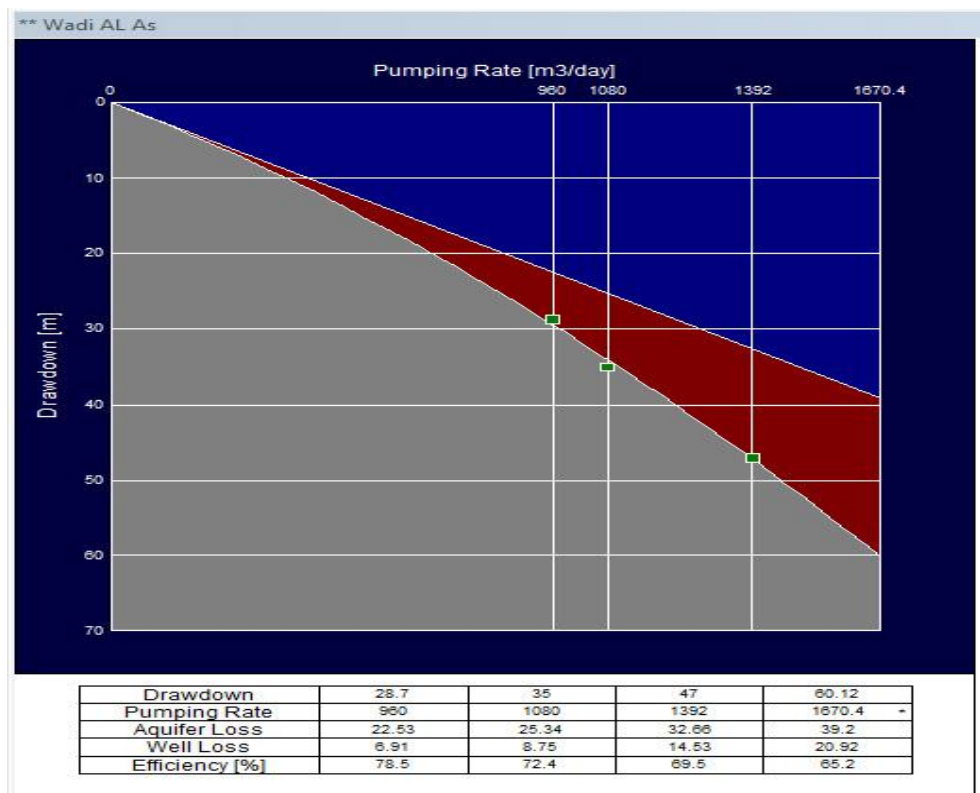

Figure 10 Analysis of Step-Drawdown Test Data of the Well: Al- Assuity. 
Table 8: Results of the Analysis of Step-Drawdown Test Data of the Well: Al-Assuity.

\begin{tabular}{|c||c|c|c|c|}
\hline Drawdown (m) & 28.7 & 35 & 47 & 60.12 \\
\hline Pumping Rate & 960 & 1080 & 1392 & 1670.4 \\
\hline Aquifer Loss & 22.53 & 25.34 & 32.66 & 39.2 \\
\hline Well Loss & 6.91 & 8.75 & 14.53 & 20.92 \\
\hline Efficiency (\%) & 78.5 & 72.4 & 69.5 & 65.2 \\
\hline
\end{tabular}

Probability of Accidence :By applying the formula $G(x)=1 / T$ (Ponce, 1989), that describes the relationship between the probability of accidence $\mathrm{G}(\mathrm{x})$, and return period $\mathrm{T}$ formula $\mathrm{T}=(\mathrm{N}+1) / \mathrm{m}$ (Brook, 1986), and based on the rainfall records of Assuit meteorological station during the period (1981-2010), the return period and the probability of accidence are tabulated in Table 9. The relation between the return period and the annual rainfall depth was plotted using a semi log paper; Figure 11.

Table 9 Wadi Al- Assuity Monthly Average Rainfall Depth in the Period from 1981 to 2010 Based on Assuit Meteorological Station.

\begin{tabular}{|c|c|c|c|c|c|}
\hline Month & $\begin{array}{c}\begin{array}{c}\text { Largest } \\
\text { Quantity } \\
\text { (mm/Month) }\end{array} \\
\end{array}$ & $\begin{array}{c}\text { Largest } \\
\text { Quantity } \\
\text { Rainfall (mm) } \\
\text { (Descending) }\end{array}$ & $\begin{array}{c}\text { Ran } \\
\mathbf{k} \\
(\mathbf{m}) \\
\end{array}$ & $\begin{array}{l}\text { Return } \\
\text { Period } \\
\text { (T) (Year) }\end{array}$ & $\begin{array}{c}\text { Probability } \\
\text { of Accidence } \\
(\mathbf{G}(\mathbf{x}))(\%)\end{array}$ \\
\hline January & 04.00 & 24.00 & $\overline{11}$ & 13 & 7.69 \\
\hline February & 00.09 & 10.70 & 2 & 6.50 & 15.38 \\
\hline March & 10.70 & 4.00 & 3 & 4.33 & 23.09 \\
\hline April & 01.10 & 2.00 & 4 & 3.25 & 30.77 \\
\hline May & 01.80 & 1.80 & 5 & 2.60 & 38.46 \\
\hline June & 00.00 & 1.10 & 6 & 2.17 & 46.08 \\
\hline July & 00.00 & 0.09 & 7 & 1.86 & 53.76 \\
\hline August & 00.00 & 0.10 & 8 & 1.63 & 61.35 \\
\hline September & 00.00 & 0.00 & 9 & 1.44 & 69.44 \\
\hline October & 00.10 & 0.00 & 10 & 1.30 & 76.92 \\
\hline November & 24.00 & 0.00 & 11 & 1.18 & 84.75 \\
\hline December & 02.00 & 0.00 & 12 & 1.08 & 92.59 \\
\hline
\end{tabular}


J. Environ. Sci.

Institute of Environmental Studies and Research - Ain Shams University

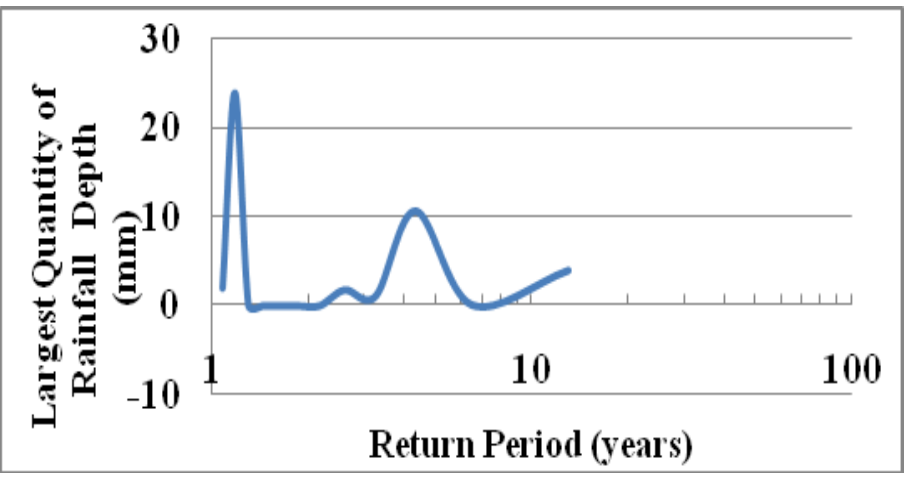

Figure 11 Relationship between the Return Period (Years) (X- Axis) and the Largest Quantity Rainfall Depth (mm) (Y- Axis) of Wadi Al- Assuity.

The relation between the largest quantity $(\mathrm{mm} / \mathrm{month})$ and the return period is inversely proportional annual, i.e. the rainfall increases; the return period becomes longer and vise versa; i.e. the annual rainfall of $24 \mathrm{~mm}$ is expected to occur each 13 years which a probability of $7.69 \%$; while the annual rainfall of $0.10 \mathrm{~mm}$ can occur every 1.63 years with a probability of accidence equal to $61.35 \%$.

Suggested Solution for Water Harvesting in Wadi Al- Assuity: Wadi AlAssuity investigation of the specific chosen storm, shows that the total amount of runoff is 4,354,242.664 $\mathrm{m}^{3}$ over a basin area of $6,049,350,000 \mathrm{~m}^{2}$, $\left(6049.350 \mathrm{~km}^{2}\right)$. The suggested solution is as follows:

* It will not be possible to do any artificial works that can hold water in $1^{\text {st }}$ and $2^{\text {nd }}$ order streams due to the high velocity and intensity of rainfall.

* It is suggested that before flood time, officials are to order labors to prepare the sight for runoff water harvesting through establishing distant rock check dams through $3^{\text {rd }}$ order streams as much as possible. Those dams are 
made of small stones covered with larger ones, and have a lower slope to the side of water slope.

* It is suggested to construct flood spreading bunds on the both sides of the stream over $4^{\text {th }}, 5^{\text {th }}$, and $6^{\text {th }}$ order streams. Officials are to order farmers to place appropriate seeds in pits and surround the side lands, by using small rocks to retain water inside them, so when the runoff stops the water remains in the soil for plant germination, and participate in nourishment of the underground aquifer.

* Small cisterns are to be distributed over $4^{\text {th }}, 5^{\text {th }}$, and $6^{\text {th }}$ order streams. Small cisterns will be side and bottom lined with permeable stone and located in places which are featured with low infiltration rate; they will be equipped with hand pumps for watering animals and irrigation. It is suggested to be placed in places near to villages, Bedouin communities, and mining locations.

* Large cisterns with concrete bodies and gravel permeable stone bottoms and equipped with pumps are to be built in specific locations after checking the infiltration rate of each location. If any of those locations is featured with high infiltration rate then it must be relocated, otherwise the soil will intake all water and no water will remain in the cistern. The larger the number of cisterns, the more water stock to be used in drought time. In addition, a lined pond connected with two large cisterns is to be constructed.

* Nine large lined collection ponds connected to two large cisterns are to be constructed on ${ }^{4 \text { th }}$ and ${ }^{5 \text { th }}$, and ${ }^{6 \text { th }}$ order streams Ponds and cisterns are to develop, serve, and irrigate the surrounding areas. 
* Two small dams and one large dam to be constructed on $6^{\text {th }}$ order stream.

* There are two mining locations in Wadi Al- Assuity: alabaster, and limestone locations as shown in the Figure 12. This location was taken into consideration in the previous solution.

* Large cisterns may be replaced by injection wells if the nature of the area allows for this; it is necessary to make sure that the underground layers contain caves and fractures to facilitate water percolation into aquifer. Figure 13 shows the distribution of rock check dams, flood spreading bunds, small cisterns, large cisterns, and large collection ponds connected to two large cisterns, two small dams, and one large dam.

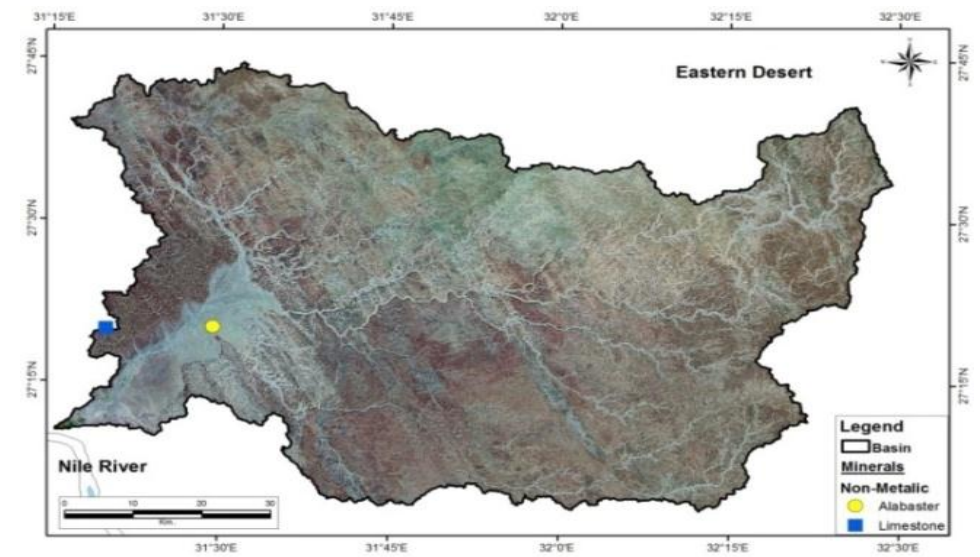

Figure 12 Mining Locations in Wadi Al- Assuity.

Source: Egyptian Geological Survey (EGS) - The Egyptian Mineral Resources Authority (EMRA). 


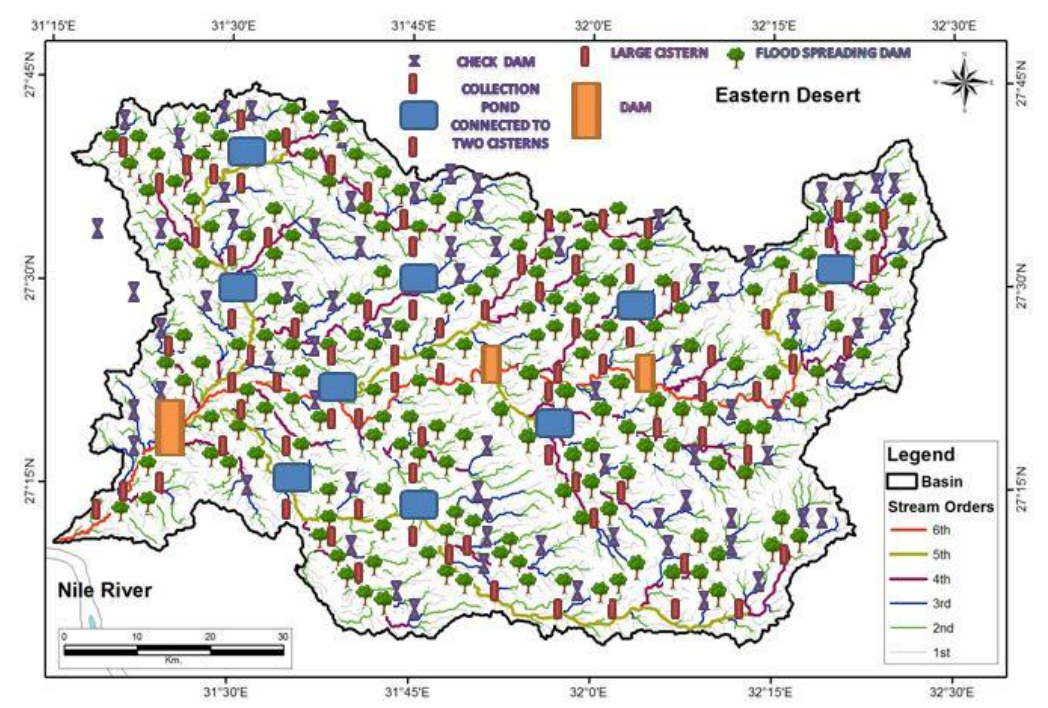

Figure 13 Suggested Water Harvesting Solution in Wadi Al- Assuity.

\section{CONCLUSION}

First: The geomorphological characteristics of Wadi Al- Assuity Basin was studied, evaluated and determined; Tables 4, 5.

Second: Climate conditions of the study area were evaluated and volume of rainfall and runoff water, which threatens the civil compounds located on the outlets of Wadi Al- Assuity basin, was estimated.

Third: The volume of floods directed to the Nile River or Red Sea, were estimated and evaluated. Maximum total volume runoff of Wadi Al- Assuity $=4,354,242.664 \mathrm{~m}^{3}$.

Fourth: The risks and threats of Wadi Al- Assuity basin through making use of the floods of water as access water source were mitigated.

Fifth: Storing of flooding water through constructing water harvesting facilities such as: check dams, flood spreading bunds, cisterns, collection 
ponds, storage dams, and others, were optimized. The stored water will be used in irrigation, animal husbandry, keeping the surrounding areas from drought, development of the surrounding areas, and keeping on the sustainable development.

Sixth: The relation between the monthly rainfall depth and the return period is inversely proportional, i.e. if the rainfall increases, the return period become longer and vise versa.

In Wadi Al- Assuity, the monthly rainfall of $24 \mathrm{~mm}$ is expected to occur each 13 years which a probability of $7.69 \%$; while the monthly rainfall of 0.10 $\mathrm{mm}$ can occur every 1.63 years with a probability of accidence equal to $61.35 \%$; Table 9.

Seventh: Suggested engineering solutions of water harvesting means were proposed to be applied; Figure 13.

Eighth: The environmental impacts of water storage means (projects) were studied and assisted and the mitigation of those impacts were proposed. The classification of the water harvesting means according to Egyptian Environmental Affairs Agency (EEAA); Table 10. 
Table 10 Suggested Engineering Solutions of Water Harvesting in Wadi AlAssuity, and the Classification of Water Harvesting Means in the Study Area according to Egyptian Environmental Affairs Agency (EEAA).

\begin{tabular}{|c|c|c|c|}
\hline $\begin{array}{l}\text { Name of the } \\
\text { Wadi }\end{array}$ & Water Harvesting Means & $\begin{array}{c}\text { Stream } \\
\text { Order }\end{array}$ & $\begin{array}{c}\text { Project } \\
\text { Classification } \\
\end{array}$ \\
\hline $\begin{array}{c}\text { Wadi } \\
\text { Al- Assuity }\end{array}$ & $\begin{array}{ll}\text { - } & \text { Check Dams } \\
\text { - } & \text { Flood Spreading Bunds } \\
\text { - } & \text { Small Cisterns } \\
\text { - } & \text { Large Cisterns } \\
\text { - } & \text { Nine Large Collection Ponds } \\
\text { Connected to Two Large } \\
\text { Cisterns } \\
\text { - Two Small Dams } \\
\text { - One Large Dam }\end{array}$ & $\begin{array}{l}3^{\text {rd }} \\
4^{\text {th }}, 5^{\text {th }}, 6^{\text {th }} \\
4^{\text {th }}, 5^{\text {th }}, 6^{\text {th }} \\
4^{\text {th }}, 5^{\text {th }}, 6^{\text {th }} \\
4^{\text {th }}, 5^{\text {th }}, 6^{\text {th }} \\
6^{\text {th }} \\
6^{\text {th }}\end{array}$ & $\begin{array}{l}\mathbf{A} \\
\mathbf{A} \\
\mathbf{A} \\
\mathbf{A} \\
\mathbf{A} \\
\mathbf{C} \\
\mathbf{C}\end{array}$ \\
\hline
\end{tabular}

\section{REFERENCES}

Brook, R. J. (1986), 'The Fascination of Statistics', CRC Press, New York.

El-Shamy, I. Z. (1992), 'New Approach for Hydrological Assessment of Hydrographic Basins of Recent Recharge and Flooding Possibilities', 10th Symp. Quaternary and Development, Mansoura University, Egypt, P.P. 15.

Hadley, R.F. and Schumm, S.A. (1961), 'Sediment Sources and Drainage Basin Characteristics in Upper Cheyenne River Basin', United States Geological Survey, Water Supply Paper 1531, Part B, 13796.

Hagget, P. (1956), Locational Analysis in Human Geography, Edward Arnold Ltd., London.

Horton, R.E. (1932), 'Drainage Basin Characteristics', Trans. Am. Geophys. Union, 13 350-361.

Horton, R.E. (1945), 'Erosional Development of Stream and their Drainage Age Basins: Hydro Physical Approach to Quantitative Morphology', Geol. Soc. Amer. Bull. 56: 275-370. 
Kumar, A. B., Jayappab, K.S. and Deepika, B. (2011), 'Prioritization of SubBasins Based on Geomorphology and Morphometric Analysis Using Remote Sensing and Geographic Information System (GIS) Techniques', Geocarto International, 26, 7:569-592.

Melton M.A, (1958), 'Correlations Structure of Morphometric Properties of drainage Systems and their Controlling Agents', Journal of Geology, 66, 442-460.

Mesa, L. M. (2006), 'Morphometric Analysis of a Subtropical Andean Basin (Tucumam, Argentina)', Environmental Geology, Vol. 50 (8), PP. $1235-1242$.

Milad, H. Masoud (2013), 'The Possible Impact of the Prevailing Physiographic Features of Selected Catchments Upon their Hydrological Characteristics, Egypt (Comparative Study)', Aust. J. Basic \& Appl. Sci.,7(14): 324-347.

Miller, V.C. (1953), 'A Quantitative Geomorphic Study of Drainage Basin Characteristics in the Clinch Mountain Area', Technical Report 3, Columbia University, Department of Geology, New York, P.P. $389-402$.

Morisawa, M.E. (1985), Rivers Forms and Process, Longman, London, P.P. 140.

Ponce, V. M. (1989), 'Engineering Hydrology Principle and Practices', Prentice Hall, New Jersey, P.P. 260-261.

Rao Liaqat A., K., Rehman, Ansari Ziaur and, and Alia, Yusuf (2011), 'Morphometric Analysis of Drainage Basin Using Remote Sensing and GIS Techniques: A Case Study of Etmadpur Tehsil, Agra district, U.P.' International Journal of Research in Chemistry and Environment, 1(2):36-45.

Schumm, S. A. (1956), 'Evolution of Drainage Systems and Slopes in Badlands at Perth Anboy, New Jersey', Bulletin of the Geological Society of America, 67: 597-646.

Smith, K.G. (1950), 'Standards for Grading Texture of Erosional Topography’, Amer. Jour. Sci., 248:655-668. 
Strahler, A. N. (1953), 'Hypsometric Analysis of Erosional Topography', Bull. Geol. Soc. Am. 63:1117-1142.

Strahler, A. N., (1964). Quantitative Geomorphology of Drainage Basins and Channel Networks. In Chow, V.T. (ed.) Handbook of Applied Hydrology, McGraw-Hill, New York. pp 439-476.

Sulaiman, M. F. Abdel Aziz (2001), 'Wadi Al- Assuity Basin: Geomorphological Study', MSc. Thesis, Ain Shams University. $\begin{array}{lllll}\text { Viewed } & \text { on } & 5 & \text { August }\end{array}$ http://drepository.asu.edu.eg/xmlui/handle/123456789/57981

Zakrzenska, B. (1967), 'Trends in Methods in Land Forms Geography: A Review Article', Annals of the Association of American. Geographers, 57, 1:121.

Zavoiance, I. (1985), 'Morphometry of Drainage Basins: (Developments in Water Science)', Elsevier Science, New York, USA, 20:104-105.

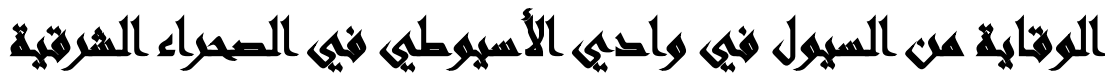

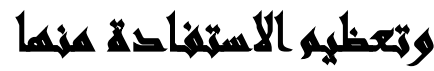

[r]

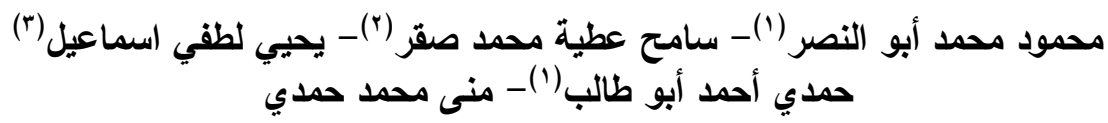

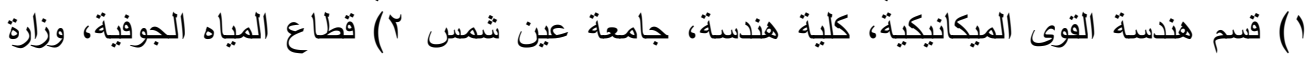

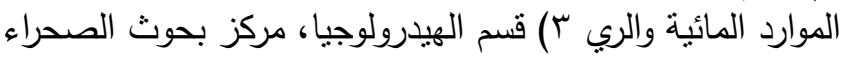

\section{(المستخطلي}

تعاني مصر حاليا من نقص في المياه، ومن المتوقع أن يزداد هذا النقص بشكل كبير كنتيجة

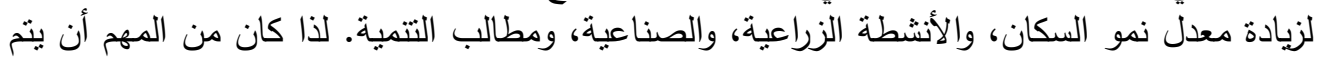

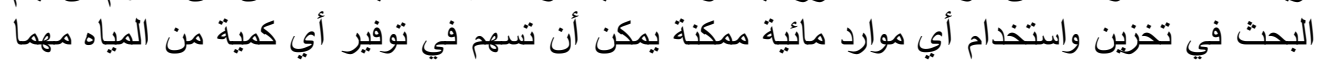

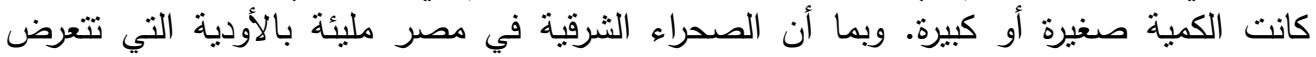

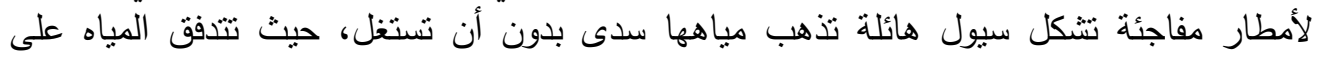

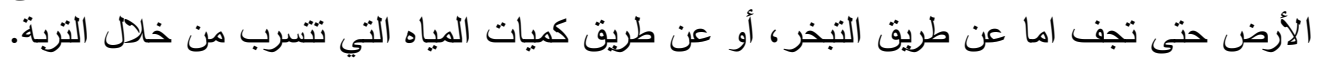


J. Environ. Sci.

Institute of Environmental Studies and Research - Ain Shams University

وعلاوة على ذلك، فقد تسبيت هذه السيول على مر السنين، في حدوث كوارث وتهديدات وتدمير للقرى

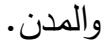

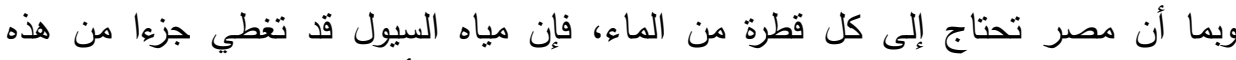

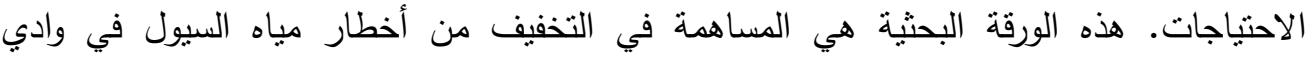
الأسيوطي في الصحراء الثرقية في مصر، وإيجاد حلول فئه عملية لتخزينها، وحماية القرى من كوارثها، واستخدام مياهها في تحقيق التتمية المستدامة في البيئة المحيطة.

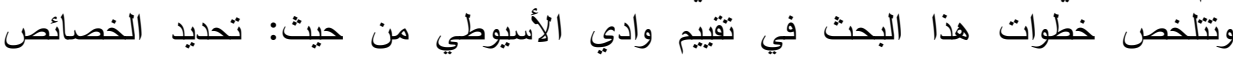

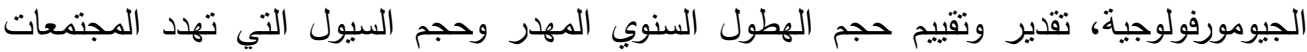

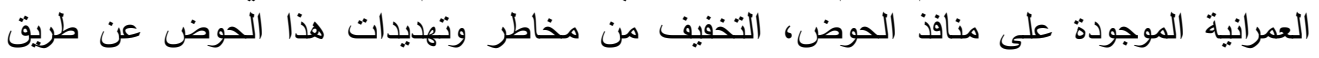

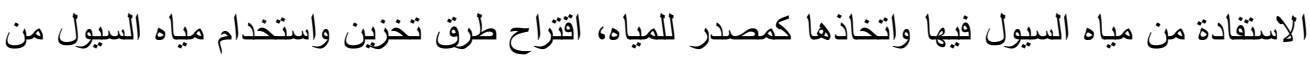

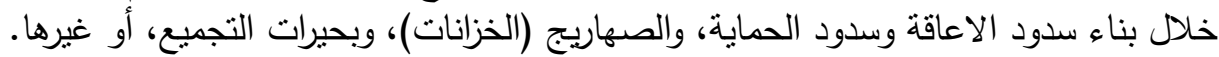

